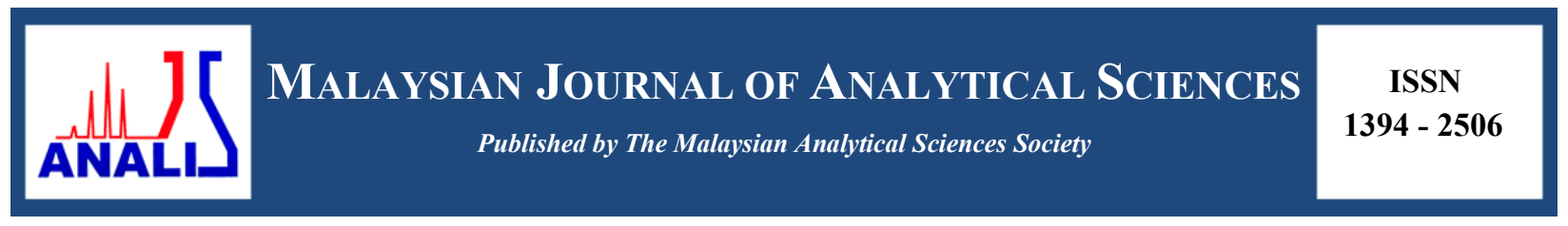

\title{
SYNTHESIS, CHARACTERIZATION AND ANTIBACTERIAL ACTIVITIES OF HYDRAZONE SCHIFF BASE COMPOUNDS AND ITS DERIVATIVES
}

\author{
(Sintesis, Pencirian dan Aktiviti Antibakteria Sebatian Bes Schiff Hidrazon dan Terbitannya) \\ Ruwaida Asyikin Abu Talip ${ }^{1 *}$, Meng Guan Tay ${ }^{1}$, Hashimatul Fatma Hashim ${ }^{2}$ \\ ${ }^{I}$ Department of Chemistry, Faculty of Resource Science and Technology \\ ${ }^{2}$ Department of Molecular Biology, Faculty of Resource Science and Technology \\ Universiti Malaysia Sarawak, 94300 Kota Samarahan, Sarawak, Malaysia \\ *Corresponding author: ruwaidaasyikinabutalip@gmail.com
}

Received: 21 August 2016; Accepted: 27 July 2017

\begin{abstract}
Biological activities (e.g. antibacterial) of hydrazone compound have received much attention from the synthetic chemists since last two decades. Herein, we would like to report the synthesis pathways as well as the spectroscopic characterization of three etherified hydrazone Schiff base compound, which were initiated from 2-hydroxyacetophenone. Hydrazone Schiff base compound was obtained through condensation reaction between 2-hydroxyacetophenone with benzhydrazide. Meanwhile the etherified derivatives of hydrazone Schiff base were prepared via Williamson ether synthesis under reflux condition. All the synthesized compounds were characterized using Fourier transformation infrared, UV-Vis and ${ }^{1} \mathrm{H}$ nuclear magnetic resonance spectroscopy. In addition, the antibacterial activities of these compounds were also conducted using disc diffusion method against Bacillus cereus and Escherichia coli. The results are discussed in this present paper.
\end{abstract}

Keywords: hydrazone Schiff base, etherified derivatives, antibacterial

\section{Abstrak}

Aktiviti biologi (contoh: antibakteria) sebatian hidrazon telah menerima banyak perhatian daripada ahli kimia sintetik sejak dua dekad yang lalu. Di sini, kami ingin melaporkan kaedah sintesis serta pencirian spektroskopi tiga hidrazon yang telah di eterifasi, dimulakan dari 2-hidroksiasetofenon. Bes-Schiff hidrazon telah diperolehi melalui tindak balas pemeluwapan antara 2hidroksiasetofenon dengan benzihidrazida. Sementara itu, terbitan yang telah di eterifasi daripada bes Schiff hidrazon telah disediakan melalui kaedah sintesis eter Williamson di bawah keadaan refluks. Semua sebatian yang disintesis dicirikan menggunakan inframerah transformasi Fourier, spektroskopi UV-Vis dan ${ }^{1} \mathrm{H}$ magnetik nukleus resonan. Di samping itu, aktiviti antibakteria sebatian ini juga dijalankan dengan menggunakan kaedah cakera penyebaran terhadap Bacillus cereus dan Escherichia coli. Keputusan dibincangkan dalam kajian ini.

Kata kunci: bes Schiff hidrazon, terbitan yang telah dieterifasi, antibakteria

\section{Introduction}

Hydrazones generally are prepared by reacting a stoichiometric amount of hydrazide $\left(\mathrm{R}-\mathrm{NH}_{-} \mathrm{NH}_{2}\right)$ and a carbonyl $(\mathrm{C}=\mathrm{O})$ compound in suitable solvent under reflux condition [1]. Hydrazone Schiff base compounds and complexes have attracted considerable amount of attention since last two decades due to their pharmaceutical activities such as antiproliferative effect, antimicrobial, antibacterial, antifungal, anti-inflammatory [2], anticonvulsant, antitubercular, antiviral, antioxidative effects and inhibition of tumor growth [3]. These biological activities enable the hydrazone 
compounds and their complexes are suitable to be used as herbicides, insecticides, nematicides, rodenticides and plant growth regulators [4].

On the other hand, compounds with long carbon chain i.e. $\mathrm{C}_{8}$ and above, received much interest from the researchers as they were reported to bear the potential as organogels in nanostructure formation [5], surfactant and in antibacterial [6]. In addition, the existence of the long carbon chain in the structure was reported to support the ability of the molecule to self-assemble into various architectures, enhance lipophilicity and antibacterial properties of the compound [6].

In this project, we report the synthesis of three hydrazone Schiff base compounds bearing carbon chains of $\mathrm{C}_{8} \mathrm{H}_{17}$, $\mathrm{C}_{10} \mathrm{H}_{21}$ and $\mathrm{C}_{12} \mathrm{H}_{25}$. The compounds were prepared by reacting etherified ketones with benzhydrazide via condensation reaction as shown in Scheme 1. Antibacterial study using disc diffusion method was conducted to find the correlation between the presences of long carbon chain with the antibacterial properties of the compound.

\section{Materials and Methods}

All ${ }^{1} \mathrm{H}$ Nuclear Magnetic Resonance (NMR) spectra were recorded by $500 \mathrm{MHz}$ of JEOL ECA-500 using $\mathrm{CDCl}_{3}$ and DMSO- $\mathrm{d}_{6}$ as solvent and TMS as internal standard for ${ }^{1} \mathrm{H}$ NMR. UV-Vis spectra were recorded using Jasco V630 spectrophotometer. The Fourier Transformation Infrared (FTIR) were recorded using Thermo Scientific Nicolet iS10.

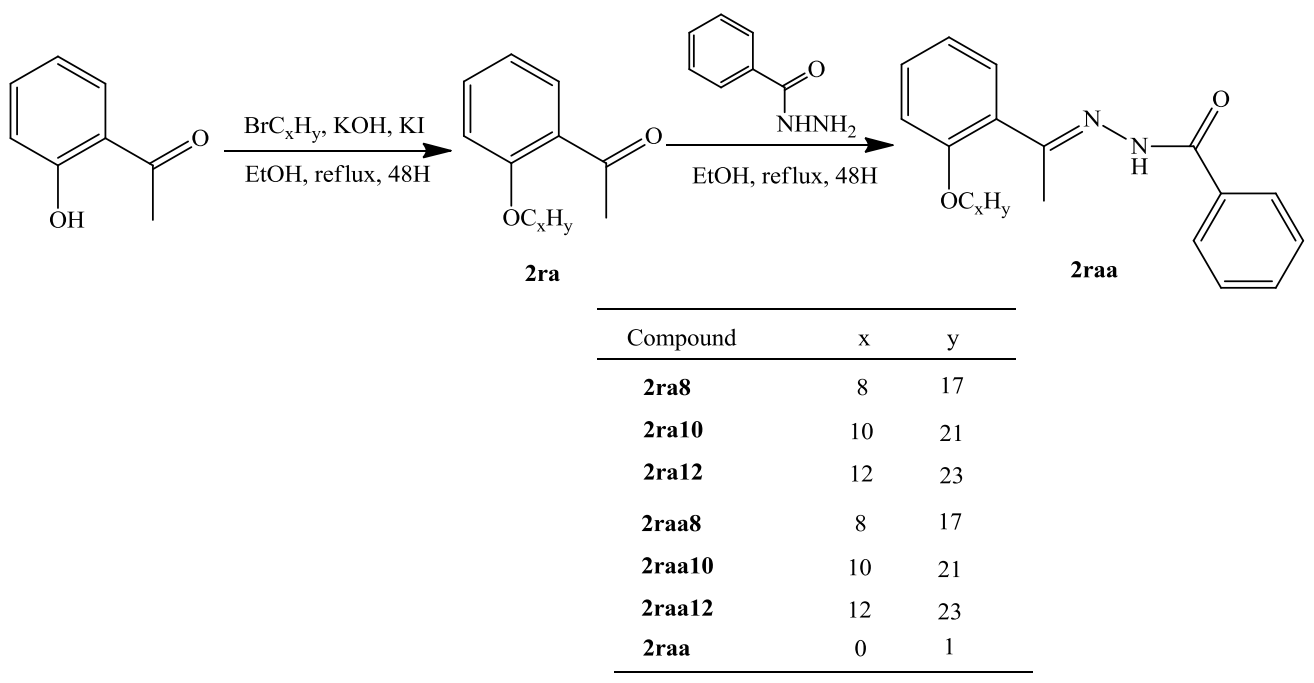

Scheme 1. Synthesis of hydrazone Schiff base compound and its derivatives

\section{Synthesis of etherified ketone: Synthesis of $2 \mathrm{ra8}$}

1-Bromooctane $(0.01 \mathrm{~mol})$ was added dropwise to the yellow ethanolic solution of 2-hydroxyacetophenone $(0.01 \mathrm{~mol})$. Pellet of potassium hydroxide $(0.01 \mathrm{~mol})$ and powder of potassium iodide $(1 \mathrm{~g})$ were added into the mixture prior before mixture was heated under reflux for 48 hours. The resulting solution which appeared in red liquid was cooled, filtered and extracted using water and diethyl ether obtaining a thick yellow liquid. Yield: $60 \%$.

\section{Synthesis of 2ra10}

The experimental procedure is similar to that in synthesis of $2 \mathbf{r a 8}$ except 1-bromooctane was replaced with 1-bromodecane. Compound 2ra10 was obtained as thick yellow liquid. Yield: $52 \%$.

\section{Synthesis of 2 ra12}

The experimental procedure is similar to that in synthesis of $2 \mathbf{r a 8}$ except 1-bromooctane was replaced with 1-bromododecane. Compound 2ra12 was obtained as thick yellow liquid. Yield: 75\%. 


\section{Synthesis of derivatives of hydrazone Schiff base: Synthesis of 2 raa8}

Benzhydrazide $(0.001 \mathrm{~mol})$ was dissolved in $20 \mathrm{ml}$ hot ethanol in a round bottom flask. To the ethanolic solution of benzhydrazide, yellow liquid of $2 \mathbf{r a 8}(0.001 \mathrm{~mol})$ was added dropwise with constant stirring and heating. The mixture was heated under reflux for 48 hours in ethanol. Resulting yellow liquid was cooled and after 3 days slow evaporation, white solid obtained. Yield: $56 \%$, white solid.

\section{Synthesis of 2 raa10}

The experimental procedure is similar to that in synthesis of $2 \mathbf{r a a 8}$ except $2 \mathbf{r a 8}$ was replaced with 2ra10 (0.001 mol). Yield: $60 \%$, pale yellow solid.

\section{Synthesis of 2 raa12}

The experimental procedure is similar to that in synthesis of 2 raa8 except 2ra8 was replaced with 2 ra12 (0.001 mol). Yield: $45 \%$, yellow solid.

\section{Synthesis of parent compound, 2-hydroxyacetophenonebenzhydrazone, 2raa}

The experimental procedure is similar to that in synthesis of $\mathbf{2} \mathbf{r a a 8}$ except $2 \mathbf{r a 8}$ was replaced with 2-hydoxyacetophenone. Yield: $89 \%$, white powder.

\section{Antibacterial evaluation of the compounds}

The assay was carried out on the parent compound (2raa) and the derivatives (2raa8 - 2raa10) using disc diffusion method [7]. One colony of Bacillus cereus ATCC 33019 from a streak plate was inoculated in $20 \mathrm{ml}$ of LuriaBertani broth. After 16 hours of incubation, the optical density of the inoculums was measured and further diluted to achieve McFarland standard of 0.5. Using sterile cotton swab, agar plate was uniformly swabbed with diluted inoculums of the bacteria before sterile filter paper $(6 \mathrm{~mm})$ which were impregnated with different concentrations of 2raa and the derivatives 2raa8-2raa10 (0.16\%-0.2\%) using DMSO as solvent were placed on the agar. The measurements of the inhibitory zones $(\mathrm{mm})$ were taken after 24 hours of incubation. The procedures were conducted in another set for Escherichia coli ATCC 35150 and were performed in triplicate.

\section{FTIR spectroscopy}

\section{Results and Discussion}

The parent compound namely, 2-hydroxyacetophenonebenzhydrazone (2raa) was prepared by reacting 2-hydroxyacetophenone with benzhydrazide under reflux using ethanol as solvent, whereas for the preparation of derivatives of hydrazone Schiff base compound, the starting material, 2-hydroxyacetophenone, was reacted with bromoalkane of $\mathrm{C} 8, \mathrm{C} 10$ and $\mathrm{C} 12$ carbons chain in the presence $\mathrm{KOH}$ and $\mathrm{KI}$ to obtain etherified ketones 2 ra8 2ra12 (Scheme 1). The presence of long carbon chain in the compounds were indicated by the presence of $\mathrm{C}-\mathrm{H}$ alkane stretching band in range of 2925.26 and $2852.54 \mathrm{~cm}^{-1}$ in IR spectrum [8]. The $\mathrm{OH}$ stretch that presence in the starting material ketone is no longer detected in the etherified ketone, 2ra8 - 2ra12 (Figure 1).

The etherified ketones, $2 \mathbf{r a 8}$ - 2ra12 were then reacted with benzhydrazide under reflux using ethanol as the solvent to obtain the derivatives of hydrazone Schiff base compounds, 2raa8 - 2raa12. The formation of the hydrazone Schiff base compounds were supported by the presence of stretching band at $3204 \mathrm{~cm}^{-1}$ attributed to the presence of N-H moiety in the hydrazone Schiff base [3]. On top of N-H band, the appearance of $\mathrm{C}=\mathrm{N}$ stretching at $1600 \mathrm{~cm}^{-1}$ also supported the formation of hydrazone Schiff base [3]. The major difference between parent ligand and the derivatives is the presence of alkane stretch at 2922.23 to $2825.42 \mathrm{~cm}^{-1}[8]$. 


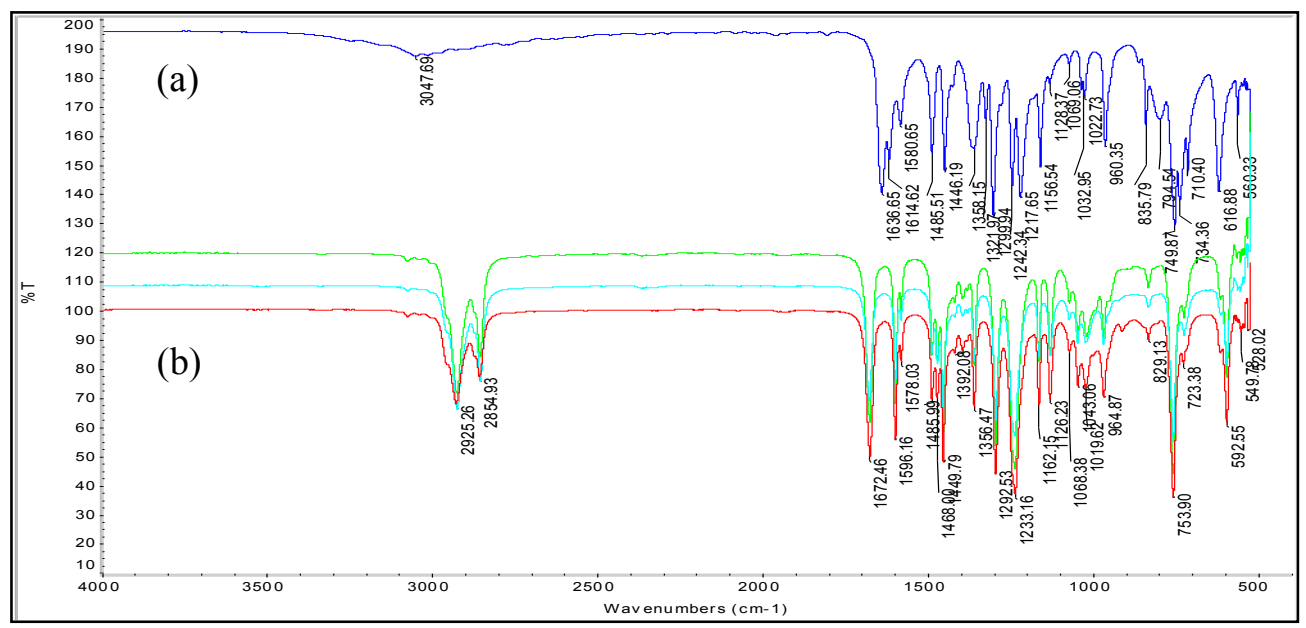

Figure 1. Infrared spectra of (a)starting material, 2-hydroxyacetophenone, (b)etherified 2-hydroxyacetophenone, 2ra8 - 2ra12

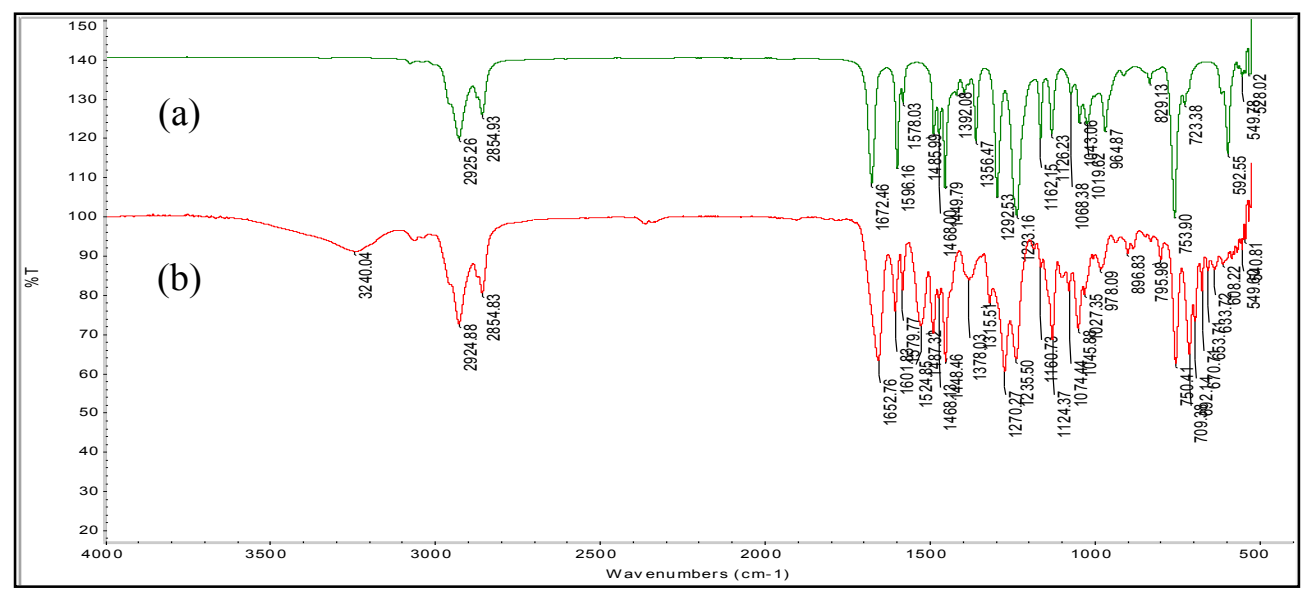

Figure 2. Infrared spectra of (a) etherified ketone, $2 \mathbf{r a 8}$ and (b) derivatives of Schiff base, 2 raa8

Table1. Summary of IR spectra stretches of the compounds

\begin{tabular}{lccccc}
\hline & $\begin{array}{c}\boldsymbol{v}(\mathbf{N H}) \\
\mathbf{c m}^{-1}\end{array}$ & $\begin{array}{c}\boldsymbol{v}(\mathbf{a l k a n e}) \\
\mathbf{c m}^{-1}\end{array}$ & $\begin{array}{c}\boldsymbol{v}(\mathbf{C}=\mathbf{O}) \\
\mathbf{c m}^{-1}\end{array}$ & $\begin{array}{c}\boldsymbol{v}(\mathbf{C}=\mathbf{N}) \\
\mathbf{c m}^{-1}\end{array}$ & $\begin{array}{c}\boldsymbol{v}(\mathbf{N}-\mathbf{N}) \\
\mathbf{c m}^{-1}\end{array}$ \\
\hline $\begin{array}{l}\text { 2-octyloxyacetophenone (2ra8) } \\
\text { 2-decyloxyacetophenone (2ra10) }\end{array}$ & - & $2925.26,2854.93$ & 1672.46 & - & - \\
$\begin{array}{l}\text { 2-dodecyloxyacetophenone (2ra12) } \\
\text { 2-octyloxyacetophenone }\end{array}$ & - & $2923.25,2853.57$ & 1673.00 & - & - \\
$\begin{array}{l}\text { benzhydrazone (2raa8) } \\
\text { 2-decyloxyacetophenone } \\
\text { benzhydrazone (2raa10) }\end{array}$ & - & $2922.31,2852.54$ & 1673.50 & - & - \\
$\begin{array}{l}\text { 2-dodecyloxyacetophenone } \\
\text { benzhydrazone (2raa12) }\end{array}$ & 3240.04 & $2925.88,2854.83$ & 1652.76 & 1601.80 & 896.00 \\
2-hydroxyacetophenone benzhydrazone (2raa) & 3205.95 & - & 1647.71 & 1604.13 & 894.00 \\
\hline
\end{tabular}




\section{UV-Vis}

The UV-Visible electronic spectra of parent compound, 2raa and derivatives 2raa8 - 2raa12 were measured at room temperature in ethanol solution within range 200 to $800 \mathrm{~nm}$. The data is summarized in Table 2. UV-Vis spectrum for 2raa showed 2 peaks (Figure 3) at 283 and $328 \mathrm{~nm}$ which attributed to $\pi$ to $\pi^{*}$ and $\mathrm{n}$ to $\pi^{*}$ transitions indicating the presence of benzene ring and amino $\mathrm{C}=\mathrm{N}$ respectively [7].

Table 2. Electronic absorption spectra data of the hydrazone Schiff base 2raa and derivatives

\begin{tabular}{lc}
\hline Compound & $\boldsymbol{\lambda}_{\mathbf{m}}(\mathbf{n m})$ \\
\hline 2raa & 283,328 \\
2raa8 & 273,375 \\
2raa10 & 274,375 \\
2raa12 & 275,375 \\
\hline
\end{tabular}
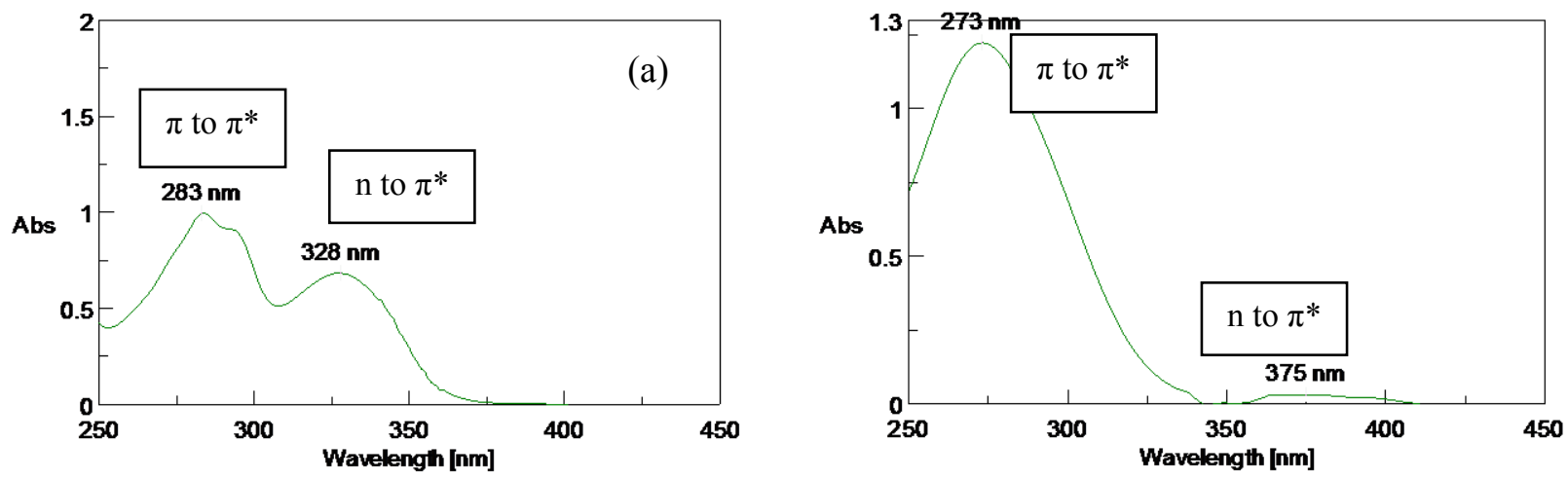

Figure 3. Electronic spectra of (a) parent compound (2raa), (b) derivative of Schiff base compound (2raa8)

Comparing the spectra of parent ligand and the derivatives, the peak of the derivatives shifted to a higher wavelength which is from 283 to $375 \mathrm{~nm}$ indicating the presence of long carbon chain in the moiety. It is known that the presence of electron donating group as substituent in aromatic molecule has significant effect on the absorption band in electronic spectra [8]. Long carbon chain is a donating group in which it decreased the energy gap between LUMO and HOMO in molecular orbital of azomethine $\mathrm{C}=\mathrm{N}$ hence resulting in lower energy, increasing the wavelength as shown in the electronic spectra of the derivatives.

\section{Nuclear magnetic resonance spectroscopy}

Comparing the NMR spectra of starting material, 2-hydroxyacetophenone and etherified ketone, 2ra8 - 2ra12, the presence long carbon chains in the $2 \mathbf{r a 8}-2 \mathrm{ra12}$ moiety were indicated by the presence of signals in range of 4.04 $0.82 \mathrm{ppm}[6]$ and disappearance of $\mathrm{OH}$ signal of hydroxyl group at meta position of starting material. Etherified ketones, 2ra8 - 2ra12 were reacted with benzhydrazide to form the derivatives of hydrazone Schiff base, 2raa8 2raa12 which were indicated by the presence of aromatic proton in the range of $7.56-6.97 \mathrm{ppm}$ with the total number of nine protons [6] representing two benzene rings in the structure of the derivatives and also the presence of NH signal at $8.90 \mathrm{ppm}$ [9]. The summary was tabulated in Table 3. 
Table 3. Summary of significant ${ }^{1} \mathrm{H}$ NMR spectral data for compounds

\begin{tabular}{|c|c|c|c|c|c|}
\hline \multirow{2}{*}{ Compounds } & \multicolumn{5}{|c|}{ Chemical Shifts, ${ }^{\delta}(\mathbf{p p m})$} \\
\hline & $\mathbf{O H}$ & NH & CH aromatic & $\mathrm{CH}_{3}$ & Alkane \\
\hline $2 \mathrm{ra8}$ & - & - & $7.71-6.91(\mathrm{~d}, \mathrm{t})$ & $2.61(\mathrm{~s})$ & $4.01(\mathrm{t}) 1.82-0.85(\mathrm{~d}, \mathrm{t})$ \\
\hline 2ra10 & - & - & $7.73-6.93(\mathrm{~d}, \mathrm{t})$ & $2.61(\mathrm{~s})$ & $4.02(\mathrm{t}), 1.83-0.87(\mathrm{~d}, \mathrm{t})$ \\
\hline 2ra12 & - & - & $7.22-6.88(\mathrm{~d}, \mathrm{t})$ & $2.60(\mathrm{~s})$ & $4.0(\mathrm{t}), 1.84-0.84(\mathrm{~d}, \mathrm{t})$ \\
\hline 2 raa8 & - & $8.9(\mathrm{~s})$ & $7.56-7.01(\mathrm{~d}, \mathrm{t})$ & $2.39(\mathrm{~s})$ & $3.99(\mathrm{t}), 1.72-0.84(\mathrm{~d}, \mathrm{t})$ \\
\hline 2raa10 & - & $8.93(\mathrm{~s})$ & $7.56-6.97(\mathrm{~d}, \mathrm{t})$ & $2.39(\mathrm{~s})$ & $3.98(\mathrm{t}), 1.71-0.74(\mathrm{~d}, \mathrm{t})$ \\
\hline 2 raa12 & - & $8.93(\mathrm{~s})$ & $7.56-7.01(\mathrm{~d}, \mathrm{t})$ & $2.38(\mathrm{~s})$ & $3.97(\mathrm{t}), 1.78-0.84(\mathrm{~d}, \mathrm{t})$ \\
\hline 2raa & $13.37(\mathrm{~s})$ & $11.34(\mathrm{~s})$ & $7.96-6.91(\mathrm{~d}, \mathrm{t})$ & $3.35(\mathrm{~s})$ & $13.37(\mathrm{~s})$ \\
\hline
\end{tabular}

$s$ : singlet, $d$ : duplet, $t$ : triplet

\section{Antibacterial activities}

Disc diffusion method was used to evaluate the antibacterial properties of the hydrazone Schiff base compound, 2raa and its long carbon chain derivatives, 2raa8 - 2raa12. Gram positive bacteria, Bacillus cereus ATCC 33019 and gram-negative bacteria, Escherichia coli ATCC 35150 were used in this study. Compounds 2raa and 2raa8 2raa12 were dissolved into the concentration of 0.16 to $0.020 \%$ using DMSO and the diameters of inhibition of the compounds were measured in $\mathrm{mm}$ unit. Inhibitions less than $10 \mathrm{~mm}$ is considered weak and insignificant, whereas more than $10 \mathrm{~mm}$ is considered moderate and more than $16 \mathrm{~mm}$ is considered significant [10]. For Bacillus cereus, the derivatives of Schiff base, 2raa8 - 2raa12 showed better antibacterial properties than the parent compound (2raa) at all concentrations (Table 4).

Table 4. Results of antibacterial properties of compounds against Bacillus cereus ATCC 33019

\begin{tabular}{lccccc}
\hline \multirow{2}{*}{ Compound } & \multicolumn{5}{c}{ Diameter of Inhibition Zone (mm) } \\
\cline { 2 - 6 } & \multicolumn{5}{c}{ Concentrations of Compounds in DMSO } \\
\hline \multirow{2}{*}{ DMSO only } & $\mathbf{0 . 1 6 \%}$ & $\mathbf{0 . 0 8 \%}$ & $\mathbf{0 . 0 4 \%}$ & $\mathbf{0 . 0 2 \%}$ \\
\cline { 3 - 6 } 2raa & - & 10 & - & - & - \\
2raa8 & & 15 & 12 & 11 & 10 \\
2raa10 & & 15 & 10 & 10 & 10 \\
2raa12 & & 11 & - & - & - \\
\hline
\end{tabular}

The azomethine group of Schiff base compound is known to possess antibacterial properties as the group have the ability to form $\mathrm{H}$ bond with the intracellular components of the bacteria and interfere with the normal cell activity thus lead to the cell death [11]. The presence of long chain in moiety of the compound has increased the lipophilicity of the compound thus assist in the penetration through the peptidoglycan of the bacteria [6]. Synergistically, the effect of these two factors has enhanced the antibacterial properties of the compound. At the concentration of $0.16 \%$, 2raa8 and 2 raa10 showed better inhibition than 2raa12. The antibacterial activity was found to increase with longer chain carbon until certain length where it reached cutoff effect where long chain no longer serves it purpose (as antibacterial agent) [6]. Hence, we can see that at 12 carbon compound namely 2 raa12 has weaker inhibition compared to 2 raa8 and 2 raa10 at $0.16 \%$. 2raa12 also showed insignificant inhibition at 0.02 $-0.08 \%$ concentration of compound. Meanwhile antibacterial screening against Escherichia coli showed that at all concentrations the incorporation of long chains into the compound (Table 5) has increased the antibacterial activities compared to the parent compound (2raa). 
Table 5. Results of antibacterial properties of compounds against Escherichia coli ATCC 35150

\begin{tabular}{lccccc}
\hline \multirow{2}{*}{ Compound } & \multicolumn{5}{c}{ Diameter of Inhibition Zone (mm) } \\
\cline { 2 - 6 } & \multicolumn{5}{c}{ Concentrations of Compounds in DMSO } \\
\cline { 2 - 6 } & DMSO only & $\mathbf{0 . 1 6 \%}$ & $\mathbf{0 . 0 8 \%}$ & $\mathbf{0 . 0 4 \%}$ & $\mathbf{0 . 0 2 \%}$ \\
\hline 2raa & - & - & - & - & - \\
2raa8 & & 11 & 10 & 10 & - \\
2raa10 & & 16 & - & - & - \\
2raa12 & & 16 & 14 & 12 & 11 \\
\hline
\end{tabular}

\section{Conclusion}

Hydrazone Schiff base compound and its long derivatives were successfully synthesized and characterized using ${ }^{1} \mathrm{H}$ NMR, UV-Vis and FTIR. Antibacterial activities of the compounds were evaluated against Bacillus cereus and Escherichia coli using disc diffusion method where long carbon chain derivatives of hydrazone Schiff base (2raa8 2raa12) showed considerable antibacterial properties compared to the parent compound (2raa). The cooperative effect in between the ability of azomethine group of Schiff base compound to disrupt the normal processes of the bacterial cell by forming $\mathrm{H}$ bond with the intracellular components of the bacterial cell and the enhancement in the lipophilicity of the compound by the incorporation of long carbon chain into the moiety of the Schiff base compound that allow easy penetration through the peptidoglycan of the bacterial cell has increased the antibacterial properties of derivatives of the hydrazone Schiff base compound. This can be observed through the antibacterial activities result where the zone inhibition of Schiff base compound was increase upon incorporation of long carbon chain into the moiety of the compound.

\section{References}

1. Solomon, T. W. G. and Fryhle, C. B. (2011). Organic chemistry asia: John Wiley \& Sons (Asia) Private Limited.

2. Charles, D., Turner, J. H. and Redmond, C. (2005). Karyotypic profiles of women after clomiphenecitrate therapy. International Journal of Obstetrics and Gynecology, 80: $264-270$.

3. Alhadi, A. A., Shaker, S. A., Yehye, W. A., Mohd Ali, H. and Abdullah, M. A. (2011). Synthesis, magnetic and spectroscopic studies of $\mathrm{Ni}(\mathrm{II}), \mathrm{Cu}(\mathrm{II}), \mathrm{Zn}(\mathrm{II})$ and $\mathrm{Cd}(\mathrm{II})$ complexes of a newly Schiff base derived from 5bromo-2-hydroxybezylidene)-3,4,5 trihydroxybenzohydrazide. Bulletin Chemical Society Ethiopia, 26(1): 95 101.

4. Shelke, V. A., Jadhav, S. M., Shankarwar, S. G., Munde, A. S. and Chondhekar, T. K. (2011). Synthesis, characterization, antibacterial and antifungal studies of some transition and rare earth metal complexes of nbenzylidene-2-hydroxybenzohydrazide. Bulletin Chemical Society Ethiopia, 25(3), 381 - 391.

5. Tan, C., Su, L., Lu, R., Xue, P., Bao, C., Liu, X. and Zhao, Y. (2006). A family of low molecular weight organogelators based on long chain substituted benzoic acid hydrazides. Journal of Molecular Liquids, 124: 32 -36 .

6. Birnie, C. R., Malamud, D. and Schaare, R. L. (2000). Antimicrobial evaluation of $n$-alkyl betaines and $n$ alkyl$n, n$-dimethylamine oxides with variations in chain length. American Society for Microbiology, 44(9): 2514 2517.

7. Osowole, A. A. (2012). Synthesis, spectroscopic characterization, in-vitro antibacterial and anti proliferative activities of some metal(ii) complexes of 3,4-dihydronaphthalen-1(2h) one schiff base. Experimental Clinical Sciences International Online Journal, 11: 338 - 345.

8. Meng Guan, T., Zainab, N., Norazilawati, M. S., Siong Wan, F. and Mee Hing, T. (2011). A convenient way for the etherification of p-hydroxyacetophenone. Research Bulletin, Faculty of Resource Science and Technology, 2: 8 - 9 . 
9. Prasanna, M. K. and Kumar, K. P. (2013). Synthesis, characterisation and evaluation of antitumour and antifungal activities of transition metal complexes of 4-pyridinecarboxylic acid [(2-hydroxyphenyl) methylene] hydrazide and its 5-methoxy derivative. International Journal Pharmceutical Biomedicine Science, 4(1): 24 29.

10. Nam, S., Kang, S. and Chang, J. (2007). Synthesis and photopolymerization of photoreactive mesogens based on chalcone. Macromolecular Research, 15(1): $74-81$.

11. Joseyphus, S. and Nair, M. (2008). Antibacterial and antifungal studies on some Schiff base complexes of zinc(II). The Korean Society of Mycology, 36(2): 93 - 98. 